\title{
QUANTITATIVE CARBON PARTITIONING DIAGRAMS FOR WASPALOY AND THEIR APPLICATION TO CHEMISTRY MODIFICA'IIONS AND PROCESSING
}

\author{
L. A. Jackman \\ H. B. Canada \\ F. E. Sczerzenie \\ Special Metals Corp., New Hartford, N.Y.
}

\begin{abstract}
Partitioning of carbon between $M C,{ }_{2}{ }_{3}{ }_{6} 6$ and solid solution was measured for Waspaloy in support of homogenization, chemistry modification, and thermomechanical processing programs. Carbon partitioning diagrams were developed for high, medium, and low carbon ingots. Analysis of wrought samples with selected heat treatments permitted extrapolation of ingot diagrams to wrought structures. Changes in carbon partitioning resulting from lower cobalt and the addition of niobium were determined.
\end{abstract}

\section{INTRODUCTION}

Properties of superalloys are influenced by the distribution and quantity of carbides. They can strengthen, initiate fracture, restrict grain boundary sliding, inhibit grain growth, tie up critical elements and participate in reactions that produce gamma prime denuded zones. The relative amounts of carbides and their distributions are dependent on factors such as chemistry, thermal treatment and microstructure. Therefore, recent programs at Special Metals on homogenization, chemistry modifications, and thermomechanical processing of Waspaloy included a study on carbon partitioning.

\section{MATERIALS AND PROCEDURE}

Chemistries of the Waspaloy heats used in this study are given in Table $I$. Heat numbers beginning with 9 represent VIM/VAR ingots $61 \mathrm{~cm}$ (24 inches) in diameter. Wrought structures were produced by rolling ingot coupons $5.08 \mathrm{~cm}$ (2 inches) thick to plates $1.27 \mathrm{~cm}$ ( 0.50 inches) thick with a final rolling temperature of $1038^{\circ} \mathrm{C}\left(1900^{\circ} \mathrm{F}\right)$. Heat numbers beginning with D1 represent VIM ingots $6.4 \mathrm{~cm}(2.5$ inches) 
Table I. Chemistries

\begin{tabular}{|c|c|c|c|c|c|c|c|c|c|c|}
\hline \multirow[b]{2}{*}{ Heat } & \multicolumn{10}{|c|}{ Wt. \% (Balance Ni) } \\
\hline & C & $\mathrm{Cr}$ & Co & Mo & $\mathrm{Ti}$ & $\mathrm{A} 1$ & $\mathrm{~B}$ & $\mathrm{Zr}$ & $\mathrm{S}$ & $\mathrm{N}$ \\
\hline $9-4747$ & .057 & 19.0 & 13.6 & 4.25 & 3.17 & 1.41 & .005 & .06 & .004 & .0030 \\
\hline $19-5750$ & 1.034 & 18.9 & 13.5 & 4.10 & 3.05 & 1.34 & .005 & .07 & .003 & .0027 \\
\hline 19-6130 & 1.020 & 19.2 & 13.6 & 4.08 & 3.09 & 1.32 & .005 & .07 & .002 & .0022 \\
\hline $9-1549$ & 1.038 & 19.1 & 13.7 & 4.25 & 3.12 & 1.37 & .005 & .07 & .003 & -- \\
\hline |D1-1650 & 1.035 & 19.4 & 13.2 & 4.05 & 3.07 & 1.35 & .004 & .06 & .001 & - \\
\hline |D1-1653 & 1.036 & 19.3 & 8.1 & 3.99 & 3.01 & 1.33 & .003 & .06 & .001 & -- \\
\hline |D1-1730 & 1.040 & 19.5 & 0.0 & 3.94 & 3.01 & 1.35 & .001 & .06 & .002 & -- \\
\hline |D1-1654* & 1.040 & 19.2 & 12.4 & 4.05 & 3.03 & 1.36 & .003 & .06 & .001 & - \\
\hline
\end{tabular}

in diameter which were also rolled to plates $1.27 \mathrm{~cm}(0.50$ inches) thick. Final rolling temperature was $1093^{\circ} \mathrm{C}\left(2000^{\circ} \mathrm{F}\right)$. Grain sizes for as rolled and selected heat treated conditions are given in Table II.

Table II. Typical Grain Sizes

\begin{tabular}{|c|c|c|c|}
\hline Heat $\mid$ Temal Rolling & Temperature & Heat Treatment & Grain Size \\
\hline $9-5750$ & $1038^{\circ} \mathrm{C}\left(1900^{\circ} \mathrm{F}\right)$ & $1010^{\circ} \mathrm{C}\left(1850^{\circ} \mathrm{F}\right) / 4 \mathrm{hrs}$ & $4-4 \frac{1}{2}$ \\
$\mid 9-5750$ & $1038^{\circ} \mathrm{C}\left(1900^{\circ} \mathrm{F}\right)$ & $1066^{\circ} \mathrm{C}\left(1950^{\circ} \mathrm{F}\right) / 17 \mathrm{hrs} . \mid 000-00,3-3 \frac{1}{2}$ \\
$|9-5750| 1038^{\circ} \mathrm{C}\left(1900^{\circ} \mathrm{F}\right)$ & $1232^{\circ} \mathrm{C}\left(2250^{\circ} \mathrm{F}\right) / 24 \mathrm{hrs} . \mid 000000-00000$ \\
$|\mathrm{D} 1-1650| 1093^{\circ} \mathrm{C}\left(2000^{\circ} \mathrm{F}\right) \mid$ & - & $1-1 \frac{1}{2}, 4-4 \frac{1}{2}$ \\
\hline
\end{tabular}

Specimens for extraction were trimmed to remove oxidized and depleted surfaces. The (TiMo)C carbides along with small amounts of $\mathrm{TiCN}, \mathrm{TiN}$, and $\mathrm{Ti}_{4} \mathrm{C}_{2} \mathrm{~S}_{2}$ were isolated by successive extractions in a $10 \%$ bromine-methanol solution. Also, an electrolytic extraction was done in a $10 \%$ hydrochloric acid-methanol solution to isolate the phases listed above plus the $\mathrm{M}_{23} \mathrm{C}_{6}$ type chromium carbide, if present. The residues from both extractions were separated from solution by filtering. Specimens were weighed before and after extraction and extracted residues were weighed.

Carbon analyses were made on the MC carbide residues isolated by bromine methanol to calculate the percent of total carbon present as MC. These results include the small amounts of carbon present as $\mathrm{Ti}(\mathrm{CN})$ and $\mathrm{Ti}_{4} \mathrm{C}_{2} \mathrm{~S}_{2}$. The weight percent of $\mathrm{M}_{23} \mathrm{C}_{6}$ carbide was determined by difference between the bromine and electrolytic extractions. 
Based on previous determinations, 5 weight percent was used as the amount of carbon in $\mathrm{M}_{23} \mathrm{C}_{6}$ for calculating the percent of total carbon as $\mathrm{M}_{23} \mathrm{C}_{6}$. $\mathrm{X}$-ray diffraction analyses were also conducted on the residues of the electrolytic extraction to confirm the presence of $\mathrm{M}_{23} \mathrm{C}_{6}$. All samples were done in duplicate.

\section{RESULTS AND DISCUSSION}

Basic carbon partitioning diagrams were determined from ingot samples heated to $1232^{\circ} \mathrm{C}\left(2250^{\circ} \mathrm{F}\right)$ for 24 hours and water quenched followed by precipitation at specific temperatures for 17 hours and water quenching.

Ingot Structure $-0.057 \%$ C. Figure 1 shows the basic carbon partitioning diagram for $0.057 \% \mathrm{C}$. The amount of $\mathrm{C}$ that did not go into solution at $1232^{\circ} \mathrm{C}\left(2250^{\circ} \mathrm{F}\right)$ has been designated primary $M C$ over the entire temperature range. Although almost $80 \%$ of the $\mathrm{C}$ was in solution at $1232^{\circ} \mathrm{C}$ $\left(2250^{\circ} \mathrm{F}\right)$, only about $3 \%$ was still in solution at $843^{\circ} \mathrm{C}$ $\left(1550^{\circ} \mathrm{F}\right)$. Both MC, identified as $\left(\mathrm{Ti} .8^{\mathrm{Mo}} .2\right) \mathrm{C}$, and $\mathrm{M}_{23} \mathrm{C}_{6}$, which is primarily $\left(\mathrm{Cr}_{21} \mathrm{Mo}_{2}\right) \mathrm{C}_{6}$ precipitated intragranular$1 \mathrm{y}$ and on grain boundaries. Above about $1038^{\circ} \mathrm{C}\left(1900^{\circ} \mathrm{F}\right)$, $\mathrm{M}_{23} \mathrm{C}_{6}$ did not exist. Precipitation of $\mathrm{M}_{23} \mathrm{C}_{6}$ is profuse in the temperature range $954^{\circ} \mathrm{C}\left(1750^{\circ} \mathrm{F}\right)$ to $788^{\circ} \mathrm{C}\left(1450^{\circ} \mathrm{F}\right)$,

$\%$ OF TOTAL

CARBON $\quad O$ - INGOT $-1232^{\circ} \mathrm{C} / 24 \mathrm{HRS}$./W.Q.+PPT. AT TEMP. 17HRS./W.Q.

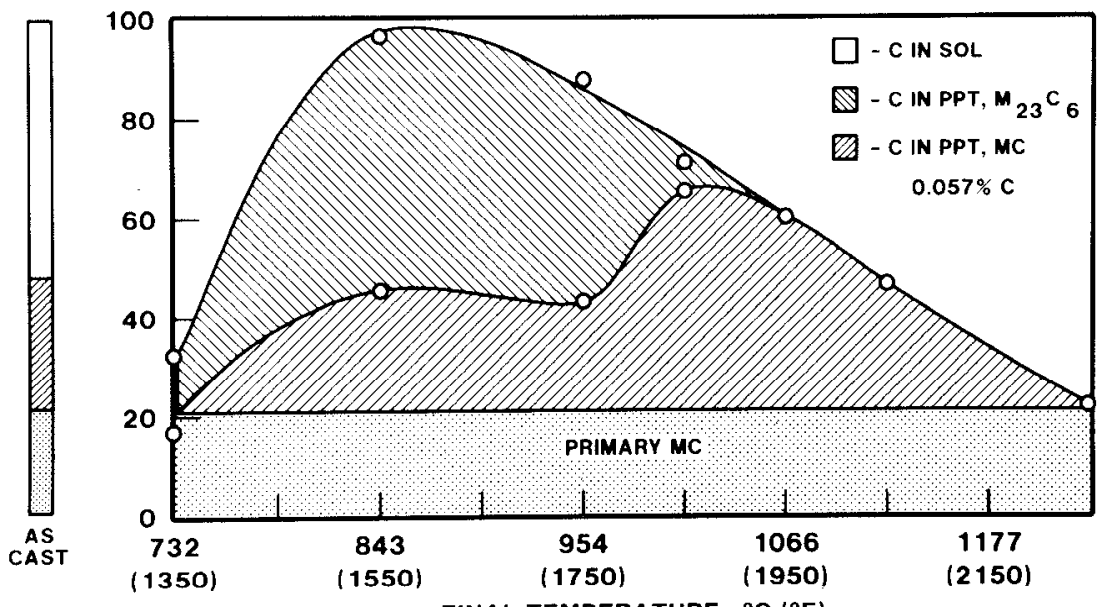

FINAL TEMPERATURE $-{ }^{\circ} \mathrm{C}\left({ }^{\circ} \mathrm{F}\right)$

Figure 1. Carbon partitioning diagram for $0.057 \% \mathrm{c}$ ingot. 
apparently due to extreme supersaturation promoting extensive nucleation on dislocations, stacking faults and other defects. Note that $\mathrm{M}_{23} \mathrm{C}_{6}$ was not present as cast.

Holding in the MC precipitation range prior to cooling into the $\mathrm{M}_{23} \mathrm{C}_{6}$ temperature range, reduced $\mathrm{C}$ supersaturation and, therefore, less $\mathrm{M}_{23} \mathrm{C}_{6}$ was precipitated. This is illustrated in Figure 2 where specimens were held at $1066^{\circ} \mathrm{C}\left(1950^{\circ} \mathrm{F}\right)$ for 17 hours and water quenched before being held at various temperatures; the amount of $\mathrm{M}_{23} \mathrm{C}_{6}$ precipitated at $843^{\circ} \mathrm{C}\left(1550^{\circ} \mathrm{F}\right)$ and $954^{\circ} \mathrm{C}\left(1750^{\circ} \mathrm{F}\right)$ was great $1 \mathrm{y}$ reduced. Also, a small amount of $M C$ beyond that precipitated at $1066^{\circ} \mathrm{C}\left(1950^{\circ} \mathrm{F}\right)$ precipitated at these two temperatures.
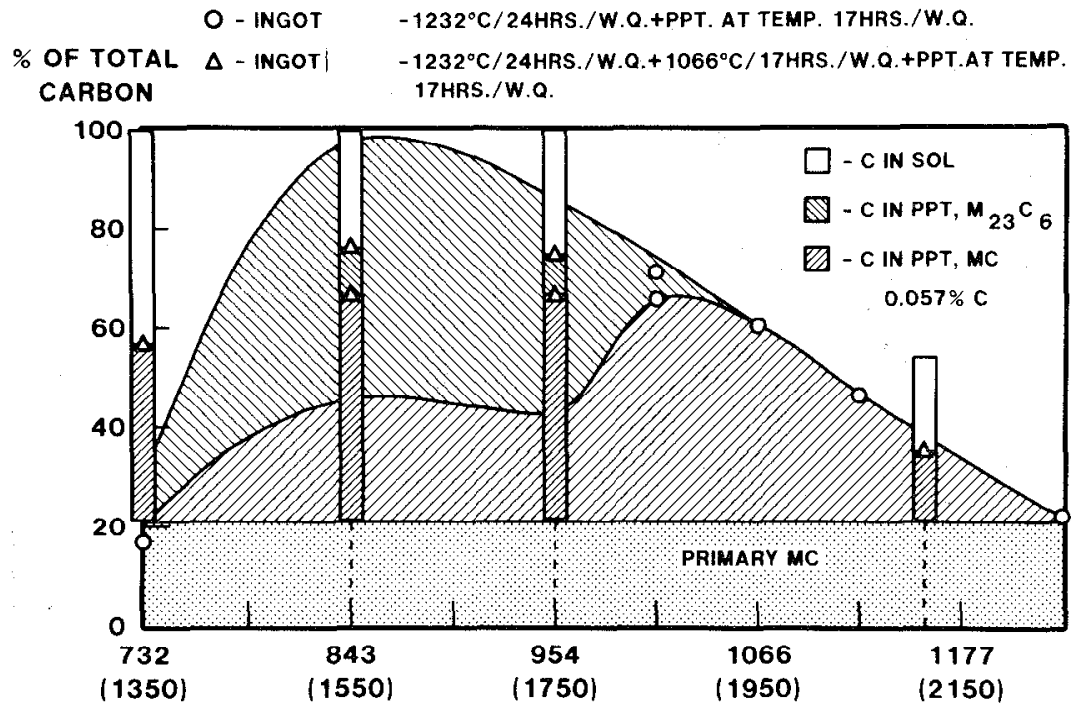

FINAL TEMPERATURE $-{ }^{\circ} \mathrm{C}\left({ }^{\circ} \mathrm{F}\right)$

Figure 2. Carbon partitioning after ho1ding at $1066^{\circ} \mathrm{C}$ before precipitating at various temperatures for $0.057 \%$ $C$ ingot.

Wrought Structure $-0.057 \% \mathrm{C}$. The basic carbon partitioning diagram for ingots is also useful for wrought structures. Holding rolled specimens at solution temperatures between $1066^{\circ} \mathrm{C}\left(1950^{\circ} \mathrm{F}\right)$ and $1232^{\circ} \mathrm{C}\left(2250^{\circ} \mathrm{F}\right)$ for 4 hours resulted in essentially the same amount of $\mathrm{MC}$ as indicated on the ingot diagram. Also 10 minutes at $1121^{\circ} \mathrm{C}\left(2050^{\circ} \mathrm{F}\right)$ was equivalent to 4 hours, indicating that carbon goes into solution very quickly at these higher temperatures. 
As shown in Figure 3 , holding at $1066^{\circ} \mathrm{C}\left(1950^{\circ} \mathrm{F}\right)$ followed by precipitation at $843^{\circ} \mathrm{C}\left(1550^{\circ} \mathrm{F}\right)$ resulted in more $\mathrm{M}_{23} \mathrm{C}_{6}$ than for the ingot structure (Figure 2). This is attributed to the presence of more grain boundaries. Also, Figure 3 illustrates that more $\mathrm{M}_{23} \mathrm{C}_{6}$ precipitates at $843^{\circ} \mathrm{C}$ $\left(1550^{\circ} \mathrm{F}\right)$ following $1010^{\circ} \mathrm{C}\left(1850^{\circ} \mathrm{F}\right)$ as compared to $1066^{\circ} \mathrm{C}$ $\left(1950^{\circ} \mathrm{F}\right)$ because of finer grain size. Holding at $1232^{\circ} \mathrm{C}$ $\left(2250^{\circ} \mathrm{F}\right)$ before holding at $1066^{\circ} \mathrm{C}\left(1950^{\circ} \mathrm{F}\right)$ resulted in essentially no $\mathrm{M}_{23} \mathrm{C}_{6}$ precipitating at $843^{\circ} \mathrm{C}\left(1550^{\circ} \mathrm{F}\right)$ in 17 hours because of extremely large grains. An indication of the rate of $\mathrm{M}_{23} \mathrm{C}_{6}$ precipitation at $843^{\circ} \mathrm{C}\left(1550^{\circ} \mathrm{F}\right)$ is given by data at 10,100 and 1020 minutes in Figure 3 .

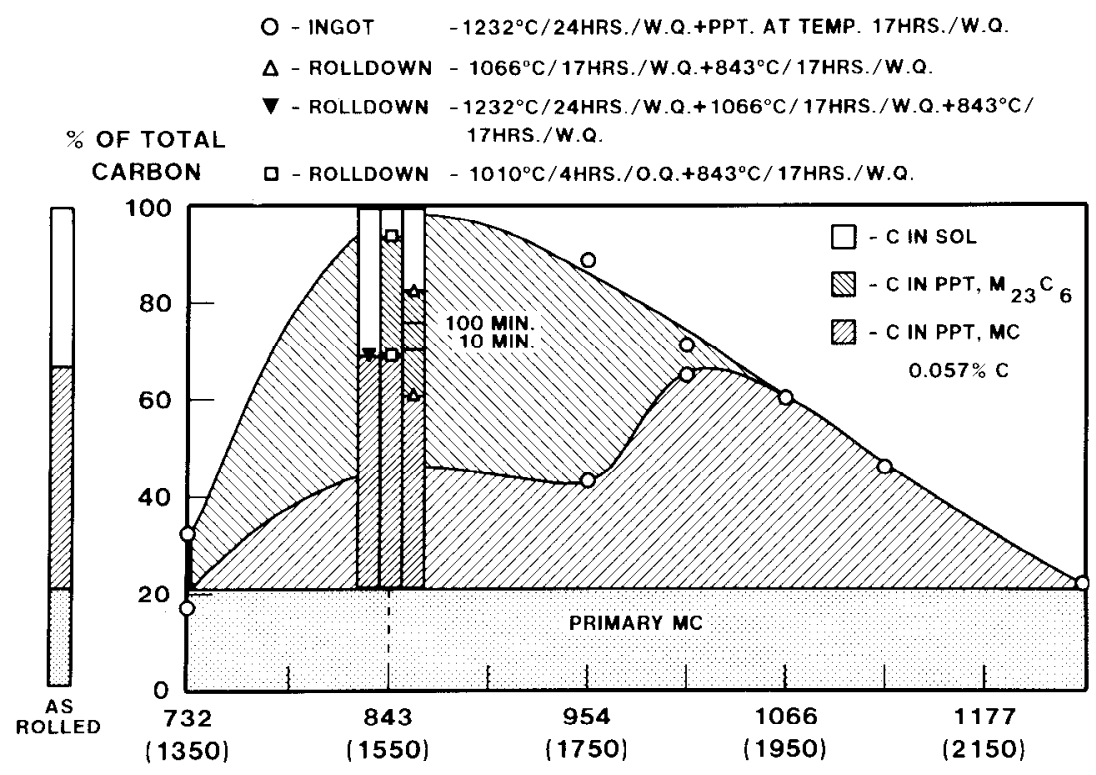

FINAL TEMPERATURE $-{ }^{\circ} \mathrm{C}\left({ }^{\circ} \mathrm{F}\right)$

Figure 3. Carbon partilioning for wrought specimens with various heat treatments for $0.057 \% \mathrm{C}$.

Ingot Structure $-0.034 \%$ and $0.020 \% \mathrm{C}$. Basic carbon partitioning diagrams are shown in Figures 4 and 5 for $0.034 \% \mathrm{C}$ and $0.020 \% \mathrm{C}$, respective1y. Again, $\mathrm{M}_{23} \mathrm{C}_{6}$ precipitates below about $1038^{\circ} \mathrm{C}\left(1900^{\circ} \mathrm{F}\right)$ and is a maximum between $843^{\circ} \mathrm{C} \quad\left(1550^{\circ} \mathrm{F}\right)$ and $984^{\circ} \mathrm{C}\left(1750^{\circ} \mathrm{F}\right)$. However, the amount of $\mathrm{M}_{23} \mathrm{C}_{6}$ is significantly less than for $0.057 \% \mathrm{C}$. The higher percentage of primary $M C$ for the lower $C$ of $0.020 \%$ is attributed to the presence of TiCN, TiN, and $\mathrm{Ti}_{4} \mathrm{C}_{2} \mathrm{~S}_{2}$ which contribute a greater proportion to the total extracted residue because fewer carbides are present. 
$\%$ OF TOTAL

CARBON O-INGOT $-1232^{\circ} \mathrm{C} / 24 \mathrm{HRS}$ / W.Q.+PPT. AT TEMP. 17HRS./W.O.
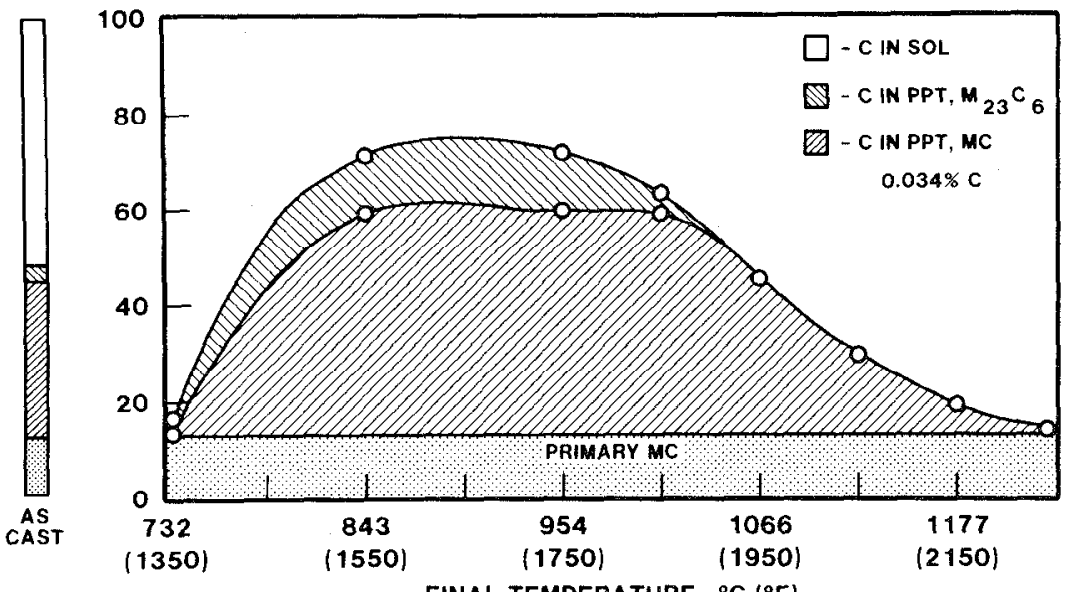

FINAL TEMPERATURE $-{ }^{\circ} \mathrm{C}\left({ }^{\circ} \mathrm{F}\right)$

Figure 4. Carbon partitioning diagram for $0.034 \% \mathrm{C}$ ingot.

\% OF TOTAL

CARBON O-INGOT $-1232^{\circ} \mathrm{C} / 24 \mathrm{HRS}$./W.Q.+PPT. AT TEMP. 17HAS./W.a.

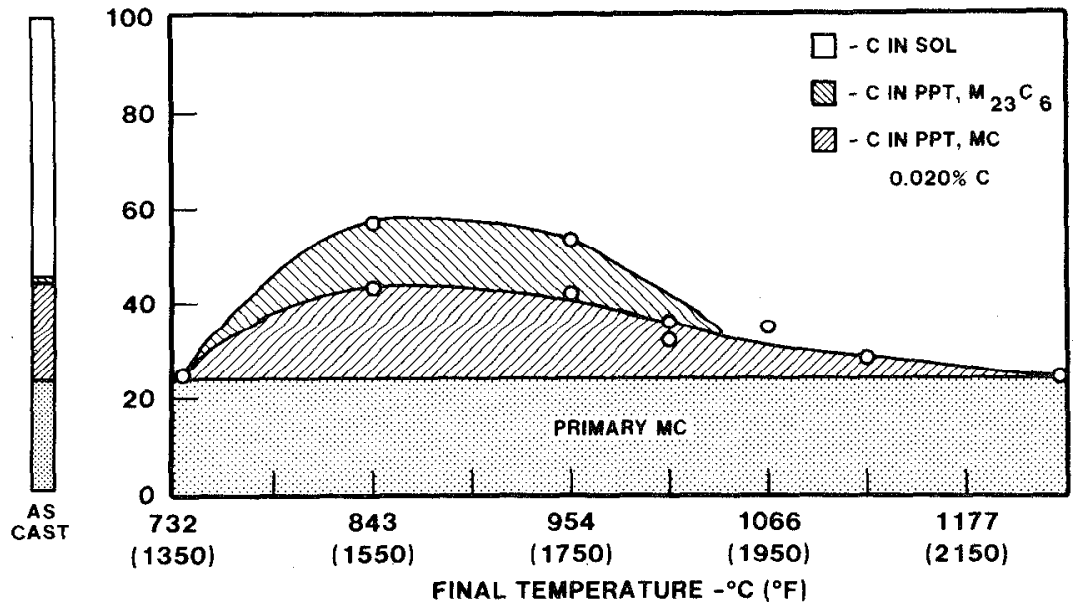

Figure 5. Carbon partitioning diagram for $0.020 \% \mathrm{C}$ ingot. 
These additional phases are more stable than MC and are not readily solutioned. The actual amount of precipitated MC was about the same for $0.057 \% \mathrm{C}$ and $0.034 \% \mathrm{C}$ in the $843^{\circ} \mathrm{C}\left(1550^{\circ} \mathrm{F}\right)$ to $954^{\circ} \mathrm{C}\left(1750^{\circ} \mathrm{F}\right)$ range. For example, multip1ication of the fraction of total C as precipitated MC by the total C yie1ds .014\% C and .015\% C as the actual amount of $\mathrm{C}$ as precipitated $\mathrm{MC}$ for $0.057 \% \mathrm{C}$ and $0.034 \%$ total $\mathrm{C}$, respectively, at $843^{\circ} \mathrm{C}\left(1550^{\circ} \mathrm{F}\right)$.

As illustrated in Figure 6 , holding at $1066^{\circ} \mathrm{C}\left(1950^{\circ} \mathrm{F}\right)$ at $843^{\circ} \mathrm{C}\left(1550^{\circ} \mathrm{F}\right)$ resulted in less precipitated MC and $\mathrm{M}_{23} \mathrm{C}_{6}$ for $0.020 \% \mathrm{C}$.

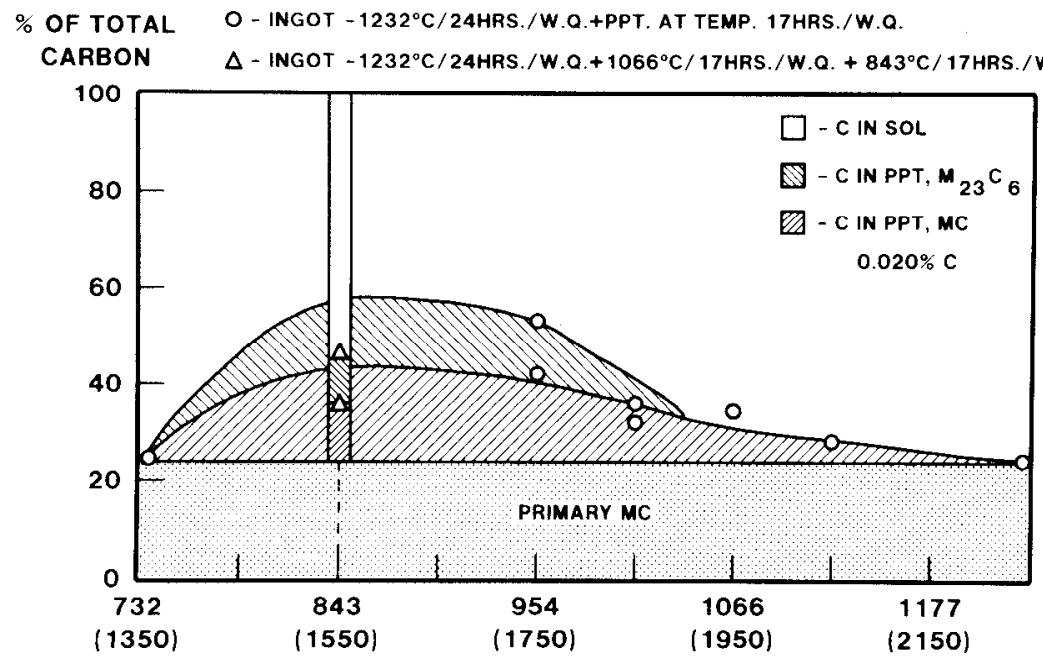

FINAL TEMPERATURE $-{ }^{\circ} \mathrm{C}\left({ }^{\circ} \mathrm{F}\right)$

Figure 6. Carbon partitioning after holding at $1066^{\circ} \mathrm{C}$ before precipitating $\mathrm{M}_{23} \mathrm{C}_{6}$ for $0.020 \% \mathrm{C}$ ingot.

Wrought structure $-0.034 \%$ and $0.020 \%$ C. Figure 7 shows that precipitation in the $843^{\circ} \mathrm{C}\left(15500^{\circ} \mathrm{F}\right)$ to $954^{\circ} \mathrm{C}$ $\left(1750^{\circ} \mathrm{F}\right)$ range after holding at $1010^{\circ} \mathrm{C}\left(1850^{\circ} \mathrm{F}\right)$ or $1066^{\circ} \mathrm{C}$ $\left(1950^{\circ} \mathrm{F}\right.$ ) resulted in more $\mathrm{M}_{23} \mathrm{C}_{6}$ than for ingot samples. Also, holding at $1010^{\circ} \mathrm{C}\left(1850^{\circ} \mathrm{F}\right)$ resulted in more $\mathrm{M}_{23} \mathrm{C}_{6}$ than holding at $1066^{\circ} \mathrm{C}\left(1950^{\circ} \mathrm{F}\right)$. Solutioning at $1232^{\circ} \mathrm{C}$ $\left(2250^{\circ} \mathrm{F}\right)$ resulted in less precipitated $\mathrm{M}_{23} \mathrm{C}_{6}$ than for ingot samples. Again, these differences in $\mathrm{M}_{23} \mathrm{C}_{6}$ precipitation are attributed to grain size differences since $\mathrm{M}_{23} \mathrm{C}_{6}$ precipitates preferentially on grain boundaries. The rate at which $\mathrm{M}_{23} \mathrm{C}_{6}$ forms is shown in Figure 7 for short $t$ imes and in Figure 8 for long exposures where MC reacts to form $M_{23} \mathrm{C}_{6}$. The values of $29 \% \mathrm{C}$ as $\mathrm{MC}$ and the remaining $71 \%$ 


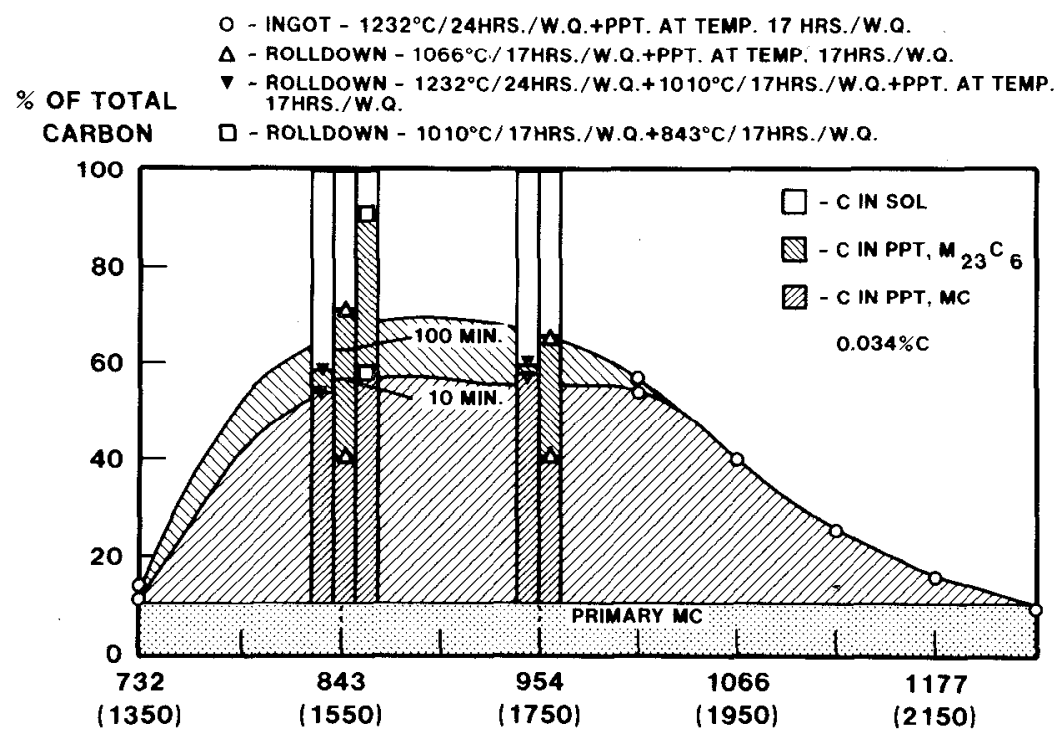

FINAL TEMPERATURE $-{ }^{\circ} \mathrm{C}\left({ }^{\circ} \mathrm{F}\right)$

Figure 7. Carbon partitioning after holding at $1010^{\circ} \mathrm{C}$, $1066^{\circ} \mathrm{C}$, or $1232^{\circ} \mathrm{C}$ before precipitating $\mathrm{M}_{23} \mathrm{C}_{6}$.

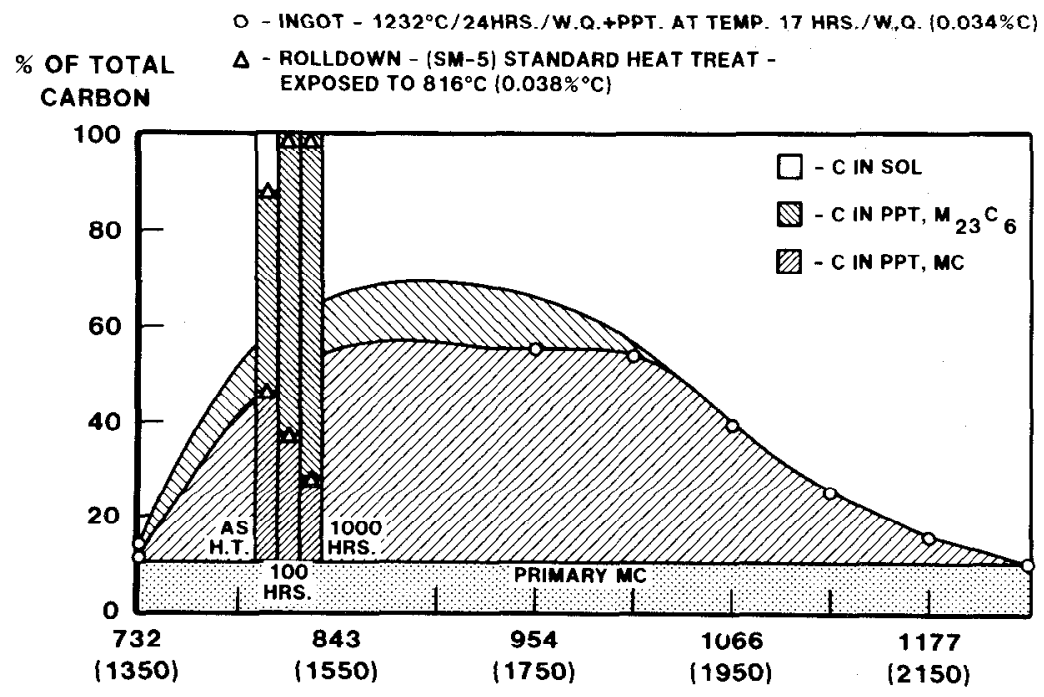

FINAL TEMPERATURE $-{ }^{\circ} \mathrm{C}\left({ }^{\circ} \mathrm{F}\right)$

Figure 8. Carbon partitioning after long exposure times for $0.038 \% \mathrm{C}$ rolldown. Standard heat treatment is $1010^{\circ} \mathrm{C} /$ $4 \mathrm{hrs.} / \mathrm{OQ}+834^{\circ} \mathrm{C} / 4 \mathrm{hrs} . / \mathrm{AC}+760^{\circ} \mathrm{C} / 16 \mathrm{hrs} . / \mathrm{AC}$. 
of total carbon as $\mathrm{M}_{23} \mathrm{C}_{6}$ for 1000 hours is in good agreement with the corresponding values of $27 \% \mathrm{C}$ and $73 \% \mathrm{C} \mathrm{calcu}-$ lated from R. F. Decker's (1) regression analysis. These data are also consistent with that of H. E. Collins (2).

Reduced Cobalt. Recent and projected shortages of Co have prompted programs directed towards lowering Co in Waspaloy. One mechanism by which decreased Co may influence properties is by altering the amount and distribution of carbides. Therefore, carbon partitioning was evaluated for rolldowns from small ingots with various Co levels. Some results are presented in Figure 9 where they are compared to the basic carbon partitioning diagram for $0.034 \% \mathrm{C}$. Lowering Co did not affect solutioning at $1232^{\circ} \mathrm{C}\left(2250^{\circ} \mathrm{F}\right)$ but did increase precipitation of MC during rolling and increased the amount of $\mathrm{M}_{23} \mathrm{C}_{6}$ at $843^{\circ} \mathrm{C}\left(1550^{\circ} \mathrm{F}\right)$. The tendency towards increased $\mathrm{M}_{23} \mathrm{C}_{6}$ formation at $843^{\circ} \mathrm{C}\left(1550^{\circ} \mathrm{F}\right)$ continued with precipitation times of 100 and 1000 hours for other experimental heats with about $0.025 \% \mathrm{C}$; at 1000 hours, $13.1 \%$ co had $72 \% \mathrm{M}_{23} \mathrm{C}_{6}$ compared to about $88 \%$ for $8.0 \%$ and $0.0 \%$ Co. Additional data are needed to determine if increasing $M C$ with decreasing $C o$ in the as-rolled condition is due to an increase in the rate of MC precipitation or an increase in the equilibrium amount of MC at the rolling temperatures.

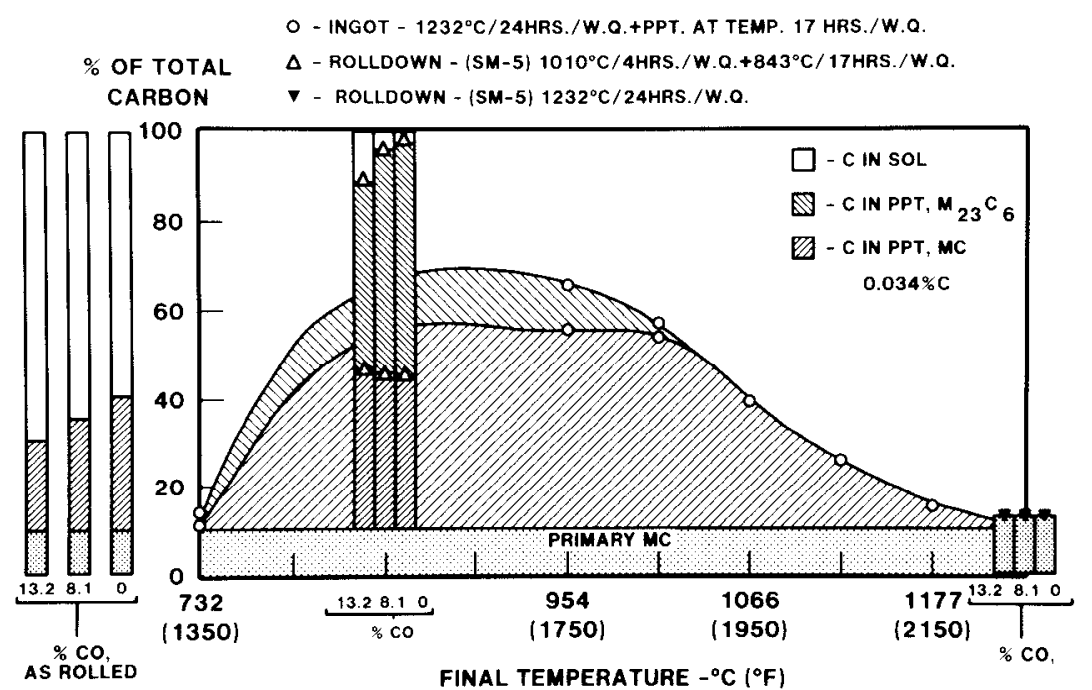

Figure 9. Effect of reduced cobalt on carbon partitioning of rolldowns with about $0.035 \% \mathrm{C}$. 
$\mathrm{Nb}$ Addition. As shown in Figure 10, the addition of only $0.41 \% \mathrm{Nb}$ significantly increased MC stability. Less MC went into solution at $1232^{\circ} \mathrm{C}\left(2250^{\circ} \mathrm{F}\right)$. Also, more MC was present after rolling and after precipitation at $843^{\circ} \mathrm{C}$ $\left(1550^{\circ} \mathrm{F}\right)$ fo 11 owing a $1010^{\circ} \mathrm{C}\left(1850^{\circ} \mathrm{F}\right)$ hold for 4 hours. Apparently the entire MC field of the carbon partitioning diagram was raised.

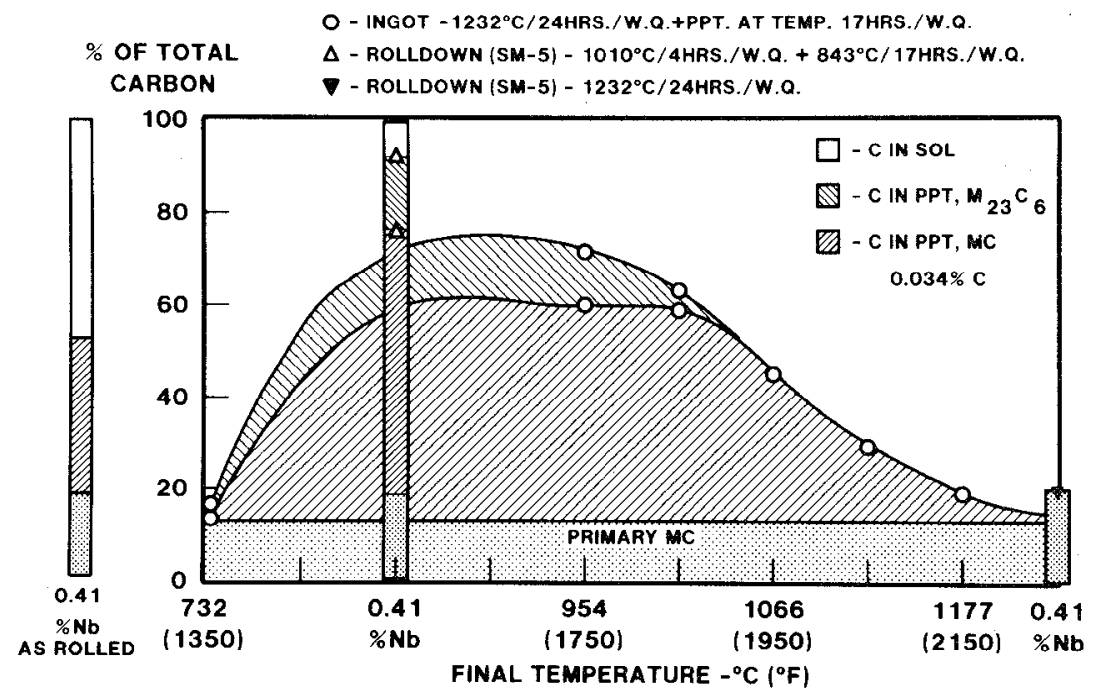

Figure 10. Effect of $0.41 \%$ niobium on carbon partitioning of rolldown with $0.040 \% \mathrm{C}$.

\section{ACKNOWLEDGEMENTS}

The authors wish to thank G. F. Baechle for specimen preparation, John Domingue for carbon partitioning data on low cobalt Waspaloy, and D. Green for scanning electron microscopy results.

\section{REFERENCES}

(1) R. F. Decker, "Strengthening Mechanisms in Nicke1-Base Superalloys," Climax Molybdenum Company Symposium, Zurick, Switzer1and, May 5-6, 1969.

(2) H. E. Collins, "Relative Long-Time Stability of Carbides and Intermetallic Phases in Nicke1-Base Superalloys," Trans. ASM, Volume 62, 1969, P. 82. 